\title{
Production Optimization and In Vitro Evaluation of Anti-Proliferative, Anti-Oxidant and Anti- Inflammatory Potential of the Antibacterial Peptide MAFP9
}

\section{Rekha Mol Kollakalnaduvil Raghavan}

Cochin University of Science and Technology

Manzur Ali Pannippara ( $D$ manzur@mesmarampally.org )

MES College Marampally https://orcid.org/0000-0002-4532-9390

\section{Sapna Kesav}

Cochin University of Science and Technology

\section{Abraham mathew}

Cochin University of Science and Technology

\section{Sarita G Bhat}

Cochin University of Science and Technology

\section{Mohamed Hatha A A}

Cochin University of Science and Technology

\section{Elyas K K}

University of Calicut

\section{Research Article}

Keywords: Antibacterial peptide, anti-proliferative, Aspergillus fumigatus, MFAP9, optimization

Posted Date: June 24th, 2021

DOI: https://doi.org/10.21203/rs.3.rs-547246/v1

License: (c) (i) This work is licensed under a Creative Commons Attribution 4.0 International License. Read Full License 


\section{Abstract}

Peptides are important natural bioactive agents obtained from various sources including microbes, plants and animals. The present study involved the optimization and physicochemical characterization of an antibacterial peptide MFAP9 produced by a marine fungus Aspergillus fumigatus BTMF9 and its vitro evaluation of antiproliferative, antioxidant and anti-inflammatory potential. Antiproliferative activity was performed using A549 lung carcinoma and normal L929 fibroblast cell lines employing MTT assay method. Antioxidant activity was assessed using DPPH assay and Cox2 inhibition assay of peptide treated LPS stimulated THP1 cell lines was used for anti-inflammatory studies. The results of in vitro antiproliferative activity assessment showed that MFAP9 was cytotoxic with an IC $\mathrm{C}_{50}$ value of $29 \mu \mathrm{g} / \mathrm{mL}$ towards A549 cells. Fluorescence microscopic analysis revealed apoptotic features such as chromatin condensation and alterations in the size and the shape of cells after treatment with MFAP9 at a concentration $50 \mu \mathrm{g} / \mathrm{mL}$. The DPPH radical scavenging activity of MFAP9 exhibits reasonably higher scavenging activity compared to that of standard antioxidant at same concentration level. Moreover, MFAP9 showed significant anti-inflammatory activities. Time course experiment was conducted with the Czapek- Dox medium and optimized the rate of MFAP9 production. The study on various physicochemical parameters on the stability revealed that the maximum active temperature of MAFP9 is $50^{\circ} \mathrm{C}$, stable in basic $\mathrm{pH}$ and $1 \mathrm{mM}$ concentration of $\mathrm{Ni}^{2+}, \mathrm{Cd}^{2+}$ and $\mathrm{Mg}^{2+}$ promotes the peptide activity. Hopefully, by employing the advancements in proteomics, bioinformatics, and modification strategies, MFAP9 could emerge as novel promising therapeutic drug in future for various clinical applications.

\section{Introduction}

The biodiversity of the marine environment and the associated chemical diversity constitute a practically inexhaustible resource of bioactive lead compounds for the development of therapeutic agents with anticancer, anti-inflammatory and antioxidant potential. Peptides play a vital role in inter and intra-cellular communications and cellular function. Considering the beneficial characteristics of high affinity, specificity, and low toxicity, peptides are effective substitutes for chemical drugs (Xueqin et al. 2017). There is a large variety of physiological activities induced by bioactive peptides which are mainly determined by the type, number, sequence and properties of amino acids in the peptide (Agyei and Danquah, 2012). The marine peptides have potential applications in the pharmaceutical industry owing to their bioactivities such as antimicrobial, antiviral, antitumor, antioxidative, cardioprotective, immunomodulatory, analgesic, anti-diabetic, appetite suppressing and neuroprotective activities (Cheung et al. 2015).

Bioactive peptides from various marine sources have been studied for their anticancer activity (Carniato et al. 2019). Cancer is one of the most life-threatening diseases and becomes a major growing health problem worldwide due to the lack of comprehensive early detection methods and proper medicines (Akindele et al. 2015; Khalil et al. 2018; Chanda and Nagani, 2013). Despite the significant development in biomedical field, cancer remains ambiguous especially from the therapeutic perspective and one of the 
greatest challenges to mankind (Silva et al. 2019). It is evident that AMPs derived from marine fungi have significant pharmacological activities and act as a cancer suppressant (Eghtedari et al. 2021).

Bioactive peptides exhibit immunomodulatory, anticancer potential as well as antioxidant potential. (Chakrabarti et al. 2014; Suarez-Jimenez et al. 2012). Antioxidants protect the body against reactive oxygen species (ROS), which exert oxidative damage to membrane lipids, protein and DNA. The association of chronic inflammation with the initiation and progression of various diseases such as cancers, cardiovascular diseases, fatty liver and Alzheimer's disease involve a cascade of events comprising the recruitment of inflammatory cells to the site of action, release of inflammatory mediators and resultant tissue damage. Recently, chemical and bioengineering strategies have been proposed to develop potent, selective and metabolically stable peptide preparations with low cost and reduced tendency to trigger undesired side-effects. These novel findings together with innovative techniques make antimicrobial peptides as an emerging category for clinical applications (Luong et al. 2020).

The biodiversity of marine microorganisms and their peptides enable them to be a good choice to develop commercial products which are yet to be explored. However, as more peptides originating from marine microbes are evaluated at the preclinical and clinical stages, optimization of microbial fermentation broth and development of high-throughput culture methodology will expedite the present investigation on the marine peptides for further application in pharmaceutical and nutraceutical industries (Kawanishi et al. 2011; Jaiganesh and Kumar, 2012). A recent study reported the isolation, purification and characterization of an antibacterial peptide MFAP9 from a marine A. fumigatus BTMF9 (NCBI GenBank accession No.HQ285882) as an excellent lead compound with strong antibacterial and antibiofilm potential (Raghavan et al. 2021). In the current study, optimization of medium components and culture conditions for maximum peptide production was analyzed followed by stability. Further the study evaluated the biological features, including the antiproliferative activities toward A549 cancer cell lines, antioxidant capacity based on 2,2-diphenyl-1-picrylhydrazyl (DPPH) free radical scavenging activity and determined anti-inflammatory potential employing cycloxygenase 2 inhibition assay of peptide treated LPS stimulated THP1 cell lines.

\section{Materials And Methods}

\section{Antibacterial peptide production: study on the effect of bioprocess variables by 'one-factor at-a-time method'}

Various bioprocess parameters affecting maximum peptide production under submerged fermentation were studied by one-factor at-a-time method using CD medium. The parameters included temperature, inorganic nitrogen source, organic nitrogen sources, carbon source, initial $\mathrm{pH}$, sodium chloride, incubation period, inoculum concentration, agitation, metal ions and additional inorganic nitrogen source. The effect of each parameter for maximal peptide production was evaluated and incorporated the same variable at its optimized level in the subsequent experiment to optimize next parameter. In each case, samples were 
analyzed for antibacterial activity and protein concentration using standard protocol unless otherwise mentioned (Enan et al. 1996; Bradford 1976). All the experiments were carried out in triplicates.

Time course experiment was conducted with the Czapek- Dox medium and optimized medium after onefactor- at - a - time method to ascertain the rate of peptide production. The optimized medium with selected conditions included $30^{\circ} \mathrm{C}$, sodium nitrate $(0.3 \%)$ as inorganic nitrogen source, sucrose $(3 \%)$ as carbon source, initial $\mathrm{pH} 7$, sodium chloride $(0.5 \%)$, inoculum concentration $(0.4 \%), \mathrm{Ca}^{2+}$ as metal ion $(2 \mathrm{mM})$, ammonium phosphate (1\%) as additional inorganic nitrogen source incubated at $150 \mathrm{rpm}$ for 168 $\mathrm{h}$. Samples were taken at a regular interval of $24 \mathrm{~h}$ for antibacterial activity analysis.

\section{Physico-chemical parameters on the stability and activity of peptide}

The stability of the MAFP9 has been studied using various physico-chemical parameters. Effect of various non-ionic and ionic detergents such as triton $X-100$, tween 80 , tween 20 , SDS and CTAB $(0.1 \%$ each $\mathrm{w} / \mathrm{v}$ ) on peptide activity was determined by incubating the purified peptide in each detergent for $1 \mathrm{~h}$. Effect of various metal ions was evaluated by incubation along with $1 \mathrm{mM}$ concentrations of various metals ions such as $\mathrm{Na}^{+}, \mathrm{Ca}^{2+}, \mathrm{Mg}^{2+}, \mathrm{Fe}^{3+}, \mathrm{Mn}^{2+}, \mathrm{Ni}^{2+}, \mathrm{Ba}^{2+}, \mathrm{Cd}^{2+}, \mathrm{Zn}^{2+}, \mathrm{Cu}^{2+}, \mathrm{Co}^{2+}, \mathrm{Cr}^{2+}$ and $\mathrm{Al}^{3+}$ respectively for $1 \mathrm{~h}$. The effect of reducing agents on the activity was studied by incubating the MAFP9 for $1 \mathrm{~h}$ with $\beta$-mercaptoethanol at a concentration of $20,40,60,80 \& 100 \mathrm{mM}$ and dithiothreitol at a concentration of $2,4,6,8 \& 10 \mathrm{mM}$. Impact of oxidizing agents on the activity of peptide was studied by incubating the purified peptide with dimethyl sulfoxide (1-5\%, v/v) and sodium hypochlorite at a concentration of 20, 40,60, 80 and $100 \mathrm{mM}$ for $1 \mathrm{~h}$. Effect of amino acid modifiers on the activity of peptide was studied by incubating the purified peptide with diethylpyrocarbonate $(0.1 \mathrm{M}$ Tris $\mathrm{HCl}, \mathrm{pH}-7)$ at $30^{\circ} \mathrm{C}$ for $30 \mathrm{~min}, \mathrm{PMSF}(0.05 \mathrm{M}$ Tris $\mathrm{HCl}, \mathrm{pH}-7.8)$ at $25^{\circ} \mathrm{C}$ for $120 \mathrm{~min}$, iodoacetamide $(0.1 \mathrm{M} \mathrm{Tris} \mathrm{HCl}$, $\mathrm{pH}-8$ ) at $35^{\circ} \mathrm{C}$ for $60 \mathrm{~min}$ at a concentration of 5, 10,15, 20 and $25 \mathrm{mM}$ and $\mathrm{N}$ - Bromosuccinamide $(0.1 \mathrm{M}$ Tris $\mathrm{HCl}, \mathrm{pH}-7)$ at concentrations of $1,2,3,4$ and $5 \mathrm{mM}$ at $30^{\circ} \mathrm{C}$ for $30 \mathrm{~min}$ followed by testing the antibacterial activity. Each parameter studied followed a dialysis against $0.01 \mathrm{M}$ phosphate buffer $(\mathrm{pH}$ 7.5). The samples were then lyophilized and residual activity was estimated.

\section{In vitro antiproliferative studies of peptide on cultured cell lines}

\section{Cell culture maintenance}

L929 fibroblast (Normal cell line) and A549 (lung carcinoma cell line) were the cell lines used for this study and were purchased from National Centre for Cell Sciences (NCCS), Pune, India. Dulbecco's modified Eagles media (HiMedia) supplemented with 10\% fetal bovine serum (FBS) (Invitrogen, USA) was used for cell line maintenance and grown to confluency at $37^{\circ} \mathrm{C}$ in $5 \% \mathrm{CO}_{2}$ (NBS, Eppendorf, Germany) in a humidified atmosphere in a $\mathrm{CO}_{2}$ incubator.

\section{Procedure}


The cells were trypsinized ( $500 \mu \mathrm{L}$ of $0.025 \%$ Trypsin in PBS/ $0.5 \mathrm{mM}$ EDTA solution (HiMedia)) for 2 min and passaged to $T$ flasks in complete aseptic conditions. Peptide sample was added to grown cells at a final concentration of $6.25 \mu \mathrm{g} / \mathrm{ml}, 12.5 \mu \mathrm{g} / \mathrm{mL}, 25 \mu \mathrm{g} / \mathrm{mL}, 50 \mu \mathrm{g} / \mathrm{mL}$ and $100 \mu \mathrm{g} / \mathrm{mL}$ from a stock of 0.1 $\mathrm{mg} / \mathrm{mL}$ and incubated for $24 \mathrm{~h}$. The percentage difference in cell viability was determined by standard MTT assay after $24 \mathrm{~h}$ of incubation (Arung et al. 2006). The morphological features of cells were imaged using inverted phase contrast microscope (Olympus CKX41, Japan) with Optika Pro5 CCD camera.

\section{Determination of apoptosis and necrosis by acridine orange (AO) and ethidium bromide (EB) double staining method}

DNA-binding dyes $\mathrm{AO}$ and EB (Sigma, USA) were used for the morphological detection of apoptotic and necrotic cells (Attari et al. 2009). AO is taken up by both viable and non-viable cells and emits green fluorescence if intercalated into double stranded nucleic acid (DNA). Ethidium bromide is taken up only by non-viable cells and discharges red fluorescence by intercalation into DNA. A549 cells were washed by cold PBS and then stained with a mixture of $A O(100 \mu \mathrm{g} / \mathrm{mL})$ and $E B(100 \mu \mathrm{g} / \mathrm{mL})$ at room temperature for $10 \mathrm{~min}$. The stained cells were washed twice with 1X PBS and analyzed using a fluorescence microscope in blue filter (Olympus CKX41 with Optika Pro5 camera). The cells were segregated into living cells (normal green nucleus), late apoptotic (orange-stained nuclei with chromatin condensation or fragmentation), early apoptotic (bright green nucleus with condensed or fragmented chromatin), and necrotic cells (uniformly orange-stained cell nuclei).

\section{Antioxidant activity}

DPPH radical scavenging by purified MAFP9 was estimated using the method of Liyana-Pathirana and Shahidi, 2005). A solution of $0.135 \mathrm{mM}$ DPPH in methanol was prepared and $1.0 \mathrm{~mL}$ of this solution was mixed with $100 \mu \mathrm{L}$ of peptide at different concentrations $(0.8,1.6,2.4,3.2$ and $4 \mu \mathrm{g})$. The standard antioxidant ascorbic acid in the same concentrations as that of peptide was used as positive controls. The reaction mixture was vortexed and kept in the dark at room temperature for $30 \mathrm{~min}$. The optical density of each sample was measured at $517 \mathrm{~nm}$. The ability to scavenge DPPH radical was calculated by the following equation:

Free radical scavenging activity $(\%)=$ $\underline{A}_{\text {Control }}-$ A $_{\text {Sample }} \times 100$

A control

where $A_{\text {control }}$ is the absorbance of the free radical solution (DPPH) + methanol, and $A_{\text {sample }}$ is the absorbance of the free radical solution with peptide/standard antioxidant.

\section{Determination of in vitro anti-inflammatory effect of MAFP9 on cultured THP1 cell lines}

The anti-inflammatory effect of MAFP9 was determined by assessing the inhibition of cycloxygenase enzyme (COX-2) when THP1 (Human monocytic cell lines) THP1 treated with LPS (Raheema et al. 2014). Cell line was cultured in RPMI 1640 [HiMedia] media, supplemented with 10\% heat inactivated FBS, 
antibiotics (Penicillin and Streptomycin) and 1.5\% sodium bicarbonate. The media was filtered by $0.2 \mu \mathrm{m}$ pore sized cellulose acetate filter (Sartorius) in totally aseptic conditions. The cells were then grown till $60 \%$ confluency followed by activation with $1 \mu \mathrm{LPS}(1 \mu \mathrm{g} / \mathrm{mL})$. LPS stimulated THP 1 cells were exposed with different concentrations of peptide samples $(6.25 \mu \mathrm{g} / \mathrm{ml}, 12.5 \mu \mathrm{g} / \mathrm{mL} 25 \mu \mathrm{g} / \mathrm{mL}, 50 \mu \mathrm{g} / \mathrm{mL}$ and $100 \mu \mathrm{g} / \mathrm{mL}$ ) from a stock of $1 \mathrm{mg} / \mathrm{ml}$ dissolved in $1 \%$ DMSO and incubated for 24 hours.

The crude enzyme isolation was done by spinning at $6000 \mathrm{rpm}$ for 10 minutes. Supernatant was discarded and $200 \mu \mathrm{l}$ of cell lysis buffer ( $1 \mathrm{MTris} \mathrm{HCl}, 0.25 \mathrm{M}$ EDTA, $2 \mathrm{M} \mathrm{NaCl}, 0.5 \%$ Triton) was added .The incubation was done for 30 minutes at $4{ }^{\circ} \mathrm{C}$ and enzyme assay was done in pellet suspended in a small amount of supernatant.

\section{Assay of cycloxygenase (COX-2) activity}

The assay mixture contained $100 \mathrm{mM}$ Tris- $\mathrm{HCl}$ buffer (pH. 8), $5 \mathrm{mM}$ glutathione, $5 \mu \mathrm{M}$ hemoglobin and crude enzyme supernatant. The reaction was started by the addition of $200 \mu \mathrm{M}$ arachidonic acid and incubated at $37^{\circ} \mathrm{C}$ for $20 \mathrm{~min}$. Reaction was terminated by adding $0.2 \mathrm{~mL}$ of $10 \% \mathrm{TCA}$ in $1 \mathrm{~N} \mathrm{HCl}$, mixed and $0.2 \mathrm{~mL}$ of $1 \%$ thiobarbituric acid was added. Reaction mixture kept in a boiling water bath for 20 min, cooled and centrifuged at $1000 \mathrm{rpm}$ for $3 \mathrm{~min}$. The absorbance was measured at $632 \mathrm{~nm}$ for COX activity.

\section{Results}

\section{MAFP9 production optimization by Aspergillus fumigatus BTMF9}

The incubation period at which maximum production noticed when the culture was incubated for $72 \mathrm{~h}$ and antibacterial activity $(1600 \mathrm{AU} / \mathrm{mL})$ remained stable throughout the incubation time. Agitation plays a major role by providing proper aeration for MFAP9 production during submerged fermentation. Maximum peptide production of $1600 \mathrm{AU} / \mathrm{mL}$ with specific activity, $\log _{10} 4.71 \pm 0.05 \mathrm{AU} / \mathrm{mg}$ was obtained when the culture was incubated with an agitation of $150 \mathrm{rpm}$. The effect of various metal ions on the peptide production was evaluated and among all metal ions, activity was observed when $\mathrm{Ca}^{2+}$, $\mathrm{Ba}^{2+}, \mathrm{Cr}^{2+}, \mathrm{Mn}^{2+}, \mathrm{Cu}^{2+}$ and $\mathrm{Al}^{3+}$ were added in the media. However a drastic increase in activity was obtained in presence of $\mathrm{Ca}^{2+}$ with activity of $3200 \mathrm{AU} / \mathrm{mL}$ and specific activity of $\log _{10} 4.83 \pm 0.02$ $\mathrm{AU} / \mathrm{mg}$. The effect of additional inorganic nitrogen source indicated that ammonium phosphate exhibited maximum activity, $3200 \mathrm{AU} / \mathrm{mL}$. The inoculum concentration that supports MFAP9 production was found to be ranged from $0.3-1 \%(1600 \mathrm{AU} / \mathrm{mL})$. However, the optimal inoculum concentration for maximum production was $0.4 \%$ at which antibacterial activity, $3200 \mathrm{AU} / \mathrm{mL}$ and specific activity $\left(\log _{10} 4.53 \pm 0.12\right.$ $\mathrm{AU} / \mathrm{mg})$.

The results obtained for the time course experiment for MFAP9 production after medium optimization is shown in Fig. 1 and it is evident that a significant increase in activity was occurred in optimized medium compared to Czapek -Dox medium. The peptide production was started at $72 \mathrm{~h}$ for both media, however 
the activity obtained in optimized medium $(6400 \mathrm{AU} / \mathrm{mL})$ was far higher than in unoptimized medium (1600 AU/mL). In optimized medium, the activity decreased after $120 \mathrm{~h}$ whereas in other case activity was steady throughout the incubation time. Maximum specific activity was recorded on $72 \mathrm{~h}$ for both media even though specific activity was higher in optimized medium $\left(\log _{10} 4.63 \pm 0.00 \mathrm{AU} / \mathrm{mg}\right)$.

\section{Physico-chemical parameters on the stability and activity of MAFP9}

The effect of various physico-chemical parameters on the activity of MAFP9 is depicted in the Table 1. Maximum active temperature of MAFP9 was found to be $50^{\circ} \mathrm{C}$, stable in basic $\mathrm{pH}$ and $1 \mathrm{mM}$ concentration of $\mathrm{Ni}^{2+}, \mathrm{Cd}^{2+}$ and $\mathrm{Mg}^{2+}$ promoted the antibacterial activity.

Table 1

Effect of physico-chemical parameters on the stability and activity of MAFP9

\section{Physico-chemical MFAP9 parameters}

Temperature

$\mathrm{pH}$

Detergents $(0.1 \%)$

Metal ions (1 mM)

$\mathrm{Ni}^{2+}, \mathrm{Cd}^{2+}$ and $\mathrm{Mg}^{2+}$ promotes the action.

DTT (2-10 mM)

$\beta$-mercaptoethanol

$(20-100 \mathrm{mM})$

Sodium hypochlorite

Activity decreased at higher concentrations

$(20-100 \mathrm{mM})$

DMSO (5-25 mM)

DEPC (5-25 mM)

PMSF (5-25 mM)

lodoacetamide

(5-25 mM)

$\mathrm{N}$-bromosuccinamide

$(1-5 \mathrm{mM})$
$\mathrm{Cu}^{2+}, \mathrm{Al}^{3+}$ and $\mathrm{Na}^{+}$reduce the activity

Activity reduces when treated with 8 and $10 \mathrm{mM}$ conc.

Maximum activity observed at $50^{\circ} \mathrm{C}$ and decreased at $100^{\circ} \mathrm{C}$

Very stable at basic range of $\mathrm{pH}$; complete loss of activity at $\mathrm{pH} 2$ and $\mathrm{pH}-13$

Reduction in activity when treated with Triton $X$ and loss of activity with SDS \& CTAB

Complete loss of activity when treated with 80 and $100 \mathrm{mM}$ conc.

No effect

Activity decreased at all concentrations

No effect

Activity decreased at all concentrations

Activity decreased at higher concentrations 


\section{Antiproliferative And Cytoyoxicity Of Mfap9}

A549 adenocarcinomic human alveolar basal epithelial cells were used to study antiproliferative activity of MFAP9 and Fig. 2.A shows the percentage viability of cells after peptide treatment. The results revealed that the peptide exhibited significantly higher cytotoxicity on cancer cells and the $\mathrm{IC}_{50}$ value was determined as $29 \mu \mathrm{g} / \mathrm{mL}$. The cell viability decreased considerably in a concentration-dependent manner. The morphological image of A549 cells after peptide MFAP9 treatment showed distorted cells with globular shape. Also cells got fragmented into membrane-bound particles producing irregular shapes that are smaller in size than the untreated cells (Fig. 2.B \& C). It was also found that the quantities of the cells decreased when treated with MFAP9.

The type of cell death induced by MFAP9 in A549 cells was further assessed by investigating the morphological changes after double staining with acrydine orange $(A O)$ and ethidium bromide (EB). As in (Fig. 2D, E \& F) AO penetrates into living cells, emitting green fluorescence due to intercalation into DNA while EB emits red fluorescence in the cells with an altered cell membrane. Fluorescence microscopic analysis revealed that features of apoptosis such as chromatin condensation and alterations in the size and the shape of cells after treatment with MFAP9 at a concentration $50 \mu \mathrm{g} / \mathrm{mL}$. The peptide treatment also resulted in the depletion of cell count. From the results it was evident that necrosis occurred at high concentration as increased percentage of necrotic red fluorescent cells were observed after treatment with $100 \mu \mathrm{g} / \mathrm{mL}$ concentration of MFAP9. These data indicates that the peptide MFAP9 caused damage to normal cell line only at higher concentration $\left(\mathrm{IC}_{50}-113.78 \mu \mathrm{g} / \mathrm{mL}\right)$ while cytotoxic to cancer cell line at lower concentration $\left(\mathrm{IC}_{50}-29 \mu \mathrm{g} / \mathrm{mL}\right)$. The apoptotic effect on cancer cell line and the minimal cytotoxic activity on non-cancerous cell line indicate MFAP9 is safe for possible application in cancer therapy.

\section{Antioxidant activity and in vitro anti-inflammatory effect of MFAP9}

The DPPH radical scavenging activity of the antibacterial peptide MFAP9 compared with that of standard antioxidant ascorbic acid. The results revealed that MFAP9 had a little higher scavenging activity compared to standard antioxidant at same concentration level. From the Fig. 3A, it was apparent that activity of both standard and MFAP9 was based on a concentration dependent manner. The in vitro antiinflammatory effect of MFAP9 was determined using THP1 cell lines. LPS stimulated THP1 cells were exposed with different concentrations of peptide sample. The spectroscopic analysis showed loss of activity of inflammatory enzyme COX-2 when culture supernatant incubated with peptide MFAP9 in the presence of the substrate, arachidonic acid revealed the anti-inflammatory potential of MFAP9 by competing with the substrate (Fig. 3. B).

\section{Discussion}


The fungal producers may be capable of changing the nature of the end synthesized products depending on the environmental conditions, moreover an increase in amount of bioactive compounds may be found after optimization of cultural conditions. A well understanding of the effect of culture conditions on biosynthesis may direct to better utilization of microbial sources. The availability of reports are fewer regarding the studies on effect of nutritional and cultural conditions on mycelial growth and antimicrobial metabolite production by the antagonistic fungal strains (Jain and Pundir, 2011; Ottoni et al. 2017). From the result, it was noted that the MFAP9 production was started on the 3rd day of incubation (72 h) and remained in a stationary mode till the last incubation time studied $(168 \mathrm{~h})$. As the specific activity was highest at $72 \mathrm{~h}$, that particular incubation time was considered as optimum for peptide production. Atalla et al. (2008) showed that the antibiotic compound production by a marine fungal isolate Varicosporina ramulosa increased gradually until reached the maximum after 8 days and then decreased. The requirement of 9 days incubation for the production of diketopiperazines was reported by Zheng et al. (2009). It has been illustrated that maximum antimicrobial agent production was achieved after 4 days of incubation for Cladosporium sp. (Miao and Qian, 2005), 5 days of incubation for Penicillium corylophilum (Silva et al. 2004) and 14 days of incubation for Penicillium waksmanii (Petit et al. 2004).

In shake flask cultures agitation is an important factor to get a growth and production of the compounds. It was observed that agitation at almost all rotation rates ranging from 50 to $200 \mathrm{rpm}$ gave a stable yield but it was higher for $150 \mathrm{rpm}$. Parameters such as temperature, agitation, culture and time of synthesis vary on the fungus used and shall be regulated in order to obtain the desired nanoparticle characteristics (Birla et al. 2013). The effect of agitation, temperature and initial pH on the growth rate of the shiitake mushroom Lentinula edodes (Berk) Pegler showed an increase under agitation and the generation time was found to be 1.5 days (Hiroko Hassegawa et al. 2005).

Effect of various metal ions on production of MFAP9 was studied and calcium was observed to produce a higher yield and this was incorporated into the optimized medium. In contrast to enzymes and its subunits, metal ion is a limiting factor, but for peptides this is not a critical factor. An eight-fold decrease in the activity of microplusin was observed when the medium was supplemented with $\mathrm{Cu}^{2+}$, nonetheless, the antimicrobial activity of microplusin didn't affect when other metal ions such as $\mathrm{Ca}^{2+}, \mathrm{Co}^{2+}, \mathrm{Fe}^{2+}$, $\mathrm{Mg}^{2+}, \mathrm{Mn}^{2+}$, and $\mathrm{Zn}^{2+}$ were added to the media. Overall analysis of the data indicated that the peptide exerts its activity by chelating copper ions. As a consequence, the disruption of copper homeostasis by microplusin results in deleterious changes of the bacterial respiratory profile (Silva et al., 2009). Inoculum concentration is one of the important factors in the growth of the fungal mycelia and production of the compound. If inoculum concentration is very much higher this may lead to competition and the culture may attain a stable phase and this may lead to death of the fungus, thus production efficiency may get reduced. The optimum inoculum concentration of $0.4 \%$ was observed to be favourable for production of peptide MFAP9.

Time course experiment with optimized and unoptimized media was performed and it was noted that a several fold increases in production of peptide occurred in optimized medium. The maximal antibacterial activity as well as specific activity was observed on the 3rd day of incubation in both media. The time 
course for antimicrobial agent production varies according to the strain and cultivation conditions. As evidenced that the maximum antimicrobial agent production was achieved after 4 days of incubation of Cladosporium sp (Miao and Qian, 2005), 5 days of incubation of Penicillium corylophilum (Silva et al. 2004) and for a fungal isolate SS2, production seems to be stable on the 5th and 6th days of the incubation with maximum production on the 5th day (Rajasekar et al. 2012). A typical time course study between statistically optimized and unoptimized medium was compared in case of exopolysaccharide (EPS) production by Schizophyllum commune AGMJ-1 for 18 days in shake flask conditions and found that under statistically optimized medium there was a 4 fold increase in EPS production was obtained (Joshi et al. 2013).

Nonionic detergents are generally considered as mild detergents and that they do not interact extensively with the protein surface, whereas non-specific binding of ionic detergents, particularly SDS to the protein surface may lead to protein unfolding (Mogensen et al. 2005). Tween 20, tween 80 and triton X-100 were the non- ionic detergents used to evaluate the effect on peptide. The study revealed that Triton $X$ influences the peptide by $50 \%$ reduction in activity when compared to other mild detergents. In contrast, treatment with ionic detergents like SDS and CTAB resulted in complete inactivation of peptide. In case of Plantaricin C19 produced by Lactobacillus plantarum C19 lost its activity after treatment with SDS or Triton X-100 (Atrih et al. 2001). According to Wen and Chen, (2014) the antifungal activity of PcPAF was $35 \%$ inhibited by $0.5 \%$ SDS compared with the control whereas no change was observed on the activity of PcPAF when treated with $0.5 \%$ Triton X-100 and 1\% Tween-20.

Antimicrobial peptides need to be stable in physiological conditions for therapeutic use against local or systemic infections due to the reason that the antagonism between the peptides and ionic strength in their environment may inhibit the development as novel antibiotics. In present study, the activity of peptide was enhanced by the addition of metal ions $\mathrm{Ni}^{2+}, \mathrm{Cd}^{2+}$ and $\mathrm{Mg}^{2+}$, whereas activity decreased in presence of $\mathrm{Cu}^{2+}, \mathrm{Al}^{3+}$ and $\mathrm{Na}^{+}$. Furthermore it was noted that the activity of peptide was not at all affected by the other ions such as $\mathrm{Ba}^{2+}, \mathrm{Fe}^{3+}, \mathrm{Zn}^{2+}, \mathrm{Co}^{2+}, \mathrm{Ni}^{2+}$ and $\mathrm{Ca}^{2+}$. AFP of Aspergillus giganteus was found to act by binding to the membrane or cell wall of sensitive fungi, and it was revealed that protein activity was severely reduced with $0.1 \mathrm{M} \mathrm{KCl}$ or $\mathrm{NaCl}$ (Theis et al. 2003). The antifungal activity of Pc-Arctin produced by Penicillium chrysogenum from an Arctic sediment remained intact in the presence of different ions $\left(0.5 \mathrm{M} \mathrm{K}^{+}, 0.5 \mathrm{M} \mathrm{Ca}^{2+}\right.$, and $0.01 \mathrm{M} \mathrm{Cu}^{2+}, \mathrm{Co}^{2+}$, and $\left.\mathrm{Ni}^{2+}\right)$ but was impaired when incubated with $0.5 \mathrm{M} \mathrm{Mg}^{2+}, 0.5 \mathrm{M} \mathrm{Mn}^{2+}$, and $0.03 \mathrm{M} \mathrm{Zn}^{2+}$ (Chen et al. 2013). One possible reason behind the influence of metal ions is that certain types of ions may interact with specific receptors that are targeted by antimicrobial proteins, and the saturation of these receptors could reduce the interaction between the receptors and the proteins (Skouri-Gargouri and Gargouri, 2010; Theis et al. 2003 ).

Both DTT and $\beta$-mercaptoethanol as reducing agents had a prominent influence on the activity of peptide MFAP9. It was evidenced that DTT caused significant reduction of activity, whereas complete inactivation of peptide occurred using $80 \mathrm{mM}$ concentration of $\beta$-mercaptoethanol. The sensitivity of peptide towards $\beta$-mercaptoethanol confirmed the presence of intra disulfide bond and its vital role for the stability of 
peptide. It was noted that DTT reduced the activity of the bacteriocin produced by $B$. subtilis LFB112 (Xie et al. 2009). Effect of oxidizing agents was studied by incubating the peptide with DMSO that acts as a mild oxidant and another strong oxidant sodium hypochlorite. The results shown that DMSO had no influence on the activity of peptide, whereas high concentration of sodium hypochlorite caused a decline in the activity of MFAP9. The effect of oxidizing agents on inhibitory activity of protease inhibitor isolated from Pleurotus floridanus revealed that the activity declined in a concentration dependent manner for both oxidizing agents DMSO and $\mathrm{H}_{2} \mathrm{O}_{2}$ (Pannippara et al. 2020).

Results obtained for the effect of chemical amino acid modifiers on the activity of MFAP9 indicated the presence of tryptophan, cysteine and histidine residues in the peptide and also their importance in the function of antibacterial activity. Modification of histidine residues with DEPC resulted in a sudden reduction in the activity of peptide and also observed insignificant role of higher concentrations as the inhibition percentage remained same at all the concentrations. Similar effect was observed when modification of cysteine residues with iodoacetamide was done. On the contrary, the modification with PMSF had no effect on the activity of the peptide suggested that the amino acid serine may either not present or having no role in the activity of peptide. The activity of peptide gradually decreased along with increase in concentrations of N-Bromosuccinamide, indicated the presence and significance of tryptophan residue. Similarly, a recent report of the exploration of functional groups present in the active site of an enzyme was done with the help of the determination of pKa values and group-specific reagents. The enzyme along with group-specific reagent was incubated and its effect was analysed based on activity, where the loss of activity indicated the presence of the functional group (Ambasht 2020). An earlier modification studies by Bhugaloo-Vial et al. (1999) reported the importance of tryptophan residues for the inhibitory activity of class Ila bacteriocins since those residues are known to play an indispensable role in the adsorption and orientation of amphiphilic peptides and proteins in membranes due to their capability to form both hydrogen and hydrophobic bonds with the polar and nonpolar groups of polar lipids.

A large number of studies have shown that some of the cationic antimicrobial peptides, which are toxic to bacteria but non-toxic to normal mammalian cells, exhibit a broad spectrum of cytotoxic activity against cancer cells. Such studies have considerably enhanced the significance of AMPs for their potential as clinical antibiotics (Robles-Fort et al. 2021). The in vitro antiproliferative activity of peptide was studied by using A549 lung carcinoma cell line and it was observed that the peptide was cytotoxic with an $\mathrm{IC}_{50}$ value of $29 \mu \mathrm{g} / \mathrm{mL}$ indicating promising application in cancer therapy. In addition, the influence of peptide on A549 cell death was studied by acridine orange (AO)/Ethidium bromide (EB) double staining method and fluorescence microscopic analysis revealed the features of apoptosis such as chromatin condensation and alterations in the size and the shape of cells suggested that MFAP9 could induce cell death through apoptosis. Similar apoptotic morphology was observed by treating crude skin extract from marine cat fish Tachysurus dussumieri on human colon cancer cell line HT 29 (Raja et al. 2020).

There were reports suggesting the process of excess lecithin synthesis by A549 cells resulted in pulmonary surfactant synthesis. Those surfactants may impede therapeutics during pulmonary disease 
treatment (Hohlfeld et al. 1997). It pauses challenge on anticancer drugs efficacy on A549 cell lines. In the present study, the intervention of peptide with the surfactants resulted activity against cell lines. It was also observed that the peptide acts in a concentration dependent mode. In vitro anticancer effect of fucoidan isolated from brown seaweed Turbinaria conoides was studied on A549 cell line. Similar to MFAP9, fucoidan also inhibited the growth of cancer cells in a dose-dependent manner and potent anticancer activities were $24.9-73.5 \%$ in the concentrations of $31.25-500 \mathrm{~g} / \mathrm{ml}$. The CTC50 value against the cancer cell was found to be $45 \mathrm{~g} / \mathrm{ml}$ and the CTC50 value of normal Vero cell line was 325 $\mathrm{g} / \mathrm{ml}$ (Kumari et al. 2018). Aspergillamide A, which is a peptide isolated from the mycelium of a marine sediment-derived Aspergillus strain found to demonstrate modest cytotoxicity $\left(\mathrm{IC}_{50}, 16 \mu \mathrm{g} / \mathrm{mL}\right)$ to human colon carcinoma HCT-116 cells (Lee et al. 2013). Calcaelin is a ribosome inactivating protein (RIP) from the puffball mushroom Calvatia caelata with an $\mathrm{N}$-terminal sequence resembling those of American ginseng and Chinese ginseng RIPs Calcaelin is a ribosome inactivating protein (RIP) from the puffball mushroom Calvatia caelata with an N-terminal sequence resembling those of American ginseng and Chinese ginseng RIPs, expressed anti-mitogenic activity toward spleen cells and antiproliferative activity towards tumor cells ( $\mathrm{Ng} 2005)$. There are reports suggesting that polysaccharide-proteins/peptides inhibit the tumor cells growth in vitro by activating multiple signal pathways including cell cycle arrest, DNA damage, and alteration of death inhibitors/promoters expression (Fu et al. 2011). HEG-5, a novel polysaccharide-protein purified from the fermented mycelia of Hericium erinaceus CZ-2 significantly inhibited the proliferation and colony formation of SGC-7901 cells by promoting apoptosis and cell cycle arrest at S phase (Zan et al. 2015). The results of the present study demonstrated significant inhibition of tumor cell proliferation by using direct tumor cell lysis by target cell membrane disruption. The fluorescence microscopic observation recorded to analyze the cell death after AO/EB staining showed the late and early apoptotic stages clearly.

The antioxidant activity is measured by determining the inhibition rate of oxidation processes in the presence of an antioxidant (Antolovich et al. 2002). Epidemiology and investigational studies have concerned about oxidative cellular damage arising from an imbalance between free radical generating and scavenging systems, the primary cause of cardiovascular diseases, cancer, aging etc (Halliwell et al. 1997). Because of the complexity of oxidative reactions taking place in biological systems, numerous chemical methods with different mechanisms of action have been developed to measure antioxidant potential of peptides. Among them, the DPPH-based assay was the first one to be used extensively for screening antioxidant peptides ((Chakrabarti et al. 2014). Scavenging of stable free radicals 2,2-diphenyl1-picrylhydrazyl (DPPH), an organic stable radical in its crystalline form is widely used to determine the antiradical activity of a given compound or extract. The antioxidant activity of a given compound or extract is also often associated with its radical scavenging activity (Karimi et al. 2010; Diouf et al. 2009). Current study demonstrates the free radical scavenging activity of MFAP9 in comparison with ascorbic acid at different concentrations and showed that the peptide had a comparable activity with that of standard antibiotic and the activity followed a concentration dependent mode. 
Nonsteroidal Anti-Inflammatory Drugs (NSAIDs) are among the most primarily used therapeutic invention for the treatment of pain and inflammation. It was observed that consumption of NSAIDs can lead to high incidence of gastrointestinal irritation due to the development of life-threatening gastrointestinal ulcers and also causes abnormal renal physiology. COX-2 is overexpressed in numerous premalignant and malignant lesions confirmed the significant correlation between the COX-2 inhibition activity of non steroidal anti-inflammatory drugs (NSAIDs) and their antitumor efficacies (Ceponyte et al. 2018). Thus, celecoxib (CXB), a selective COX-2 inhibitor, showed promising results in the prevention tumor cell growth and suppress tumor angiogenesis and metastasis Xu et al. 2011). A pH-sensitive nanotherapeutic system based on a marine sulfated polysaccharide demonstrated a great potential for the treatment of metastatic breast cancer by combining chemotherapy and COX-2 inhibitor (Zhang et al. 2019). In this context, the relevance of anti-inflammatory potential of peptide gets high priority. The spectrophotometric analysis showed that the peptide treatment on LPS induced cell lines could inhibit the activity of COX-2 enzyme, indicative of its anti-inflammatory potential. Das et al. (2011) reported the isolation and characterization of a novel $14 \mathrm{kD}$ a protein with antifungal and anti-inflammatory properties from Aloe vera leaf gel where the spectroscopic study showed $84.6 \%$ loss of activity of inflammatory enzymes, LOX and $73 \%$ with COX-2 when incubated with Aloe protein in the presence of substrates, linoleic acid and arachidonic acid respectively.

\section{Conclusion}

The antibacterial peptide MAFP9 demonstrated significant inhibition on tumor cell proliferation and free radical scavenging activity in comparison with ascorbic acid. In addition to that MFAP9 induced cell death through apoptosis. The media conditions were optimized and increased the production to several fold. Hence, the antibacterial peptide MAFP9 will have a guiding significance in pharmaceutics and therapeutics.

\section{Declarations}

\section{Conflict of interest}

The authors declared that they have no conflicts of interest to this work.

\section{Acknowledgement}

This work was supported by the Council of Scientific \& Industrial Research (CSIR, New Delhi) under grant No. 10-2(5)/2007 (ii) - E.U.II in the form of fellowship to the first author.

\section{References}

1. Agyei D, Danquah M (2012) Rethinking food-derived bioactive peptides for antimicrobial and immunomodulatory activities. Trends Food Sci Technol 23(2): 62-9. 
2. Akindele AJ, Wani Z, Mahajan G, Sharma S, Aigbe FR, Satti N, Adeyemi OO, Mondhe DM (2015) Anticancer activity of Aristolochia ringens Vahl. (Aristolochiaceae). J Tradit Complementary Med 5:35-41 https://doi.org/10.1016/j.jtcme.2014.05.001

3. Ambasht PK (2020) Use of Group-Specific Reagents in Active Site Functional Group Elucidation I: Cys, Ser, Tyr, and Trp Residues. Springer, Singapore

4. Antolovich M, Prenzler PD, Patsalides E, McDonald S, Robards K (2002) Methods for testing antioxidant activity.Analyst 127(1): 183-198

5. Arung ET, Shimizu K, Kondo R (2006) Inhibitory effect of artocarpanone from Artocarpus heterophyllus on melanin biosynthesis. Biol Pharm Bull 29(9): 1966-1969.

6. Atalla MM, Zeinab HK, Eman RH, Amani AY, Abeer AA (2008) Production of some biologically active secondary metabolites from marine-derived fungus Varicosporina ramulosa. Malays $\mathrm{J}$ Microbiol 4(1): $14-24$

7. Atrih A, Rekhif N, Moir AJG, Lebrihi A, Lefebvre G (2001) Mode of action, purification and amino acid sequence of plantaricin $\mathrm{C} 19$, an anti-Listeria bacteriocin produced by Lactobacillus plantarum $\mathrm{C} 19$. Int J Food Microbiol 68(1): 93-104

8. Attari F, Sepehri H, Delphi L, Goliaei B (2009) Apoptotic and necrotic effects of pectic acid on rat pituitary GH3/B6 tumor cells. Iran Biomed J 13(4):229-236

9. Bhugaloo-Vial P, Douliez JP, Mollé D, Dousset X, Boyaval P, Marion D (1999) Delineation of key amino acid side chains and peptide domains for antimicrobial properties of divercin V41, a pediocin-like bacteriocin secreted by Carnobacterium divergens V41. Appl Environ Microbiol 65(7): 2895-2900

10. Birla SS, Gaikwad SC, Gade AK, Rai MK (2013) Rapid synthesis of silver nanoparticles from Fusarium oxysporum by optimizing physicocultural conditions. Sci World J 2013:796018 doi: $10.1155 / 2013 / 796018$.

11. Bradford MM (1976) A rapid and sensitive method for the quantitation of microgram quantities of protein utilizing the principle of protein-dye binding. Anal Biochem 72(1-2): 248-254. doi:10.1016/0003-2697(76)90527-3

12. Carniato F, Alberti D, Lapadula A, Martinelli J, Isidoro C, Crich SG, Tei L (2019) Multifunctional Gdbased mesoporous silica nanotheranostic for anticancer drug delivery. J Mater Chem B 7(19): 314352.

13. Ceponyte U, Paskeviciute M, Petrikaite V (2018) Comparison of NSAIDs activity in COX-2 expressing and non-expressing 2D and 3D pancreatic cancer cell cultures. Cancer Manag Res 10: 1543

14. Chakrabarti S, Jahandideh F, Wu J (2014) Food-derived bioactive peptides on inflammation and oxidative stress. Biomed Res Int 2014 doi: http://dx.doi.org/10.1155/2014/608979

15. Chanda S, Nagani K (2013) In vitro and in vivo methods for anticancer activity evaluation and some Indian medicinal plants possessing anticancer properties: an overview. J Pharmacogn Phytochem 2:140-152

16. Chen Z, Ao J, Yang W, Jiao L, Zheng T, Chen X (2013) Purification and characterization of a novel antifungal protein secreted by Penicillium chrysogenum from an Arctic sediment. Appl Microbiol 
Biotechnol 97(24): 10381-10390

17. Cheung RC, Ng TB, Wong JH (2015) Marine peptides: Bioactivities and applications. Mar drugs 13(7): 4006-43.

18. Das S, Mishra B, Gill K, Ashraf MS, Singh AK, Sinha M, Dey S (2011) Isolation and characterization of novel protein with anti-fungal and anti-inflammatory properties from Aloe vera leaf gel. Int $\mathrm{J}$ Biol Macromol 48(1):38-43

19. Diouf PN, Stevanovic T, Cloutier A (2009) Study on chemical composition, antioxidant and antiinflammatory activities of hot water extract from Piceamariana bark and its proanthocyanidin-rich fractions. Food Chem 113(4): 897-902

20. Eghtedari M, Porzani SJ, Nowruzi B (2021) Anticancer potential of natural peptides from terrestrial and marine environments: A review. Phytochem Lett 42: 87-103 https://doi.org/10.1016/j.phytol.2021.02.008

21. Enan G, El-Essawy AA, Uyttendaele M, Debevere J (1996) Antibacterial activity of Lactobacillus plantarum UG1 isolated from dry sausage: characterization, production and bactericidal action of plantaricin UG1. Int J Food Microbiol 30(3):189-215.

22. Fu LL, Zhou CC, Yao S, Yu JY, Liu B, Bao JK (2011) Plant lectins: targeting programmed cell death pathways as antitumor agents. Int J Biochem Cell Biol 43(10): 1442-1449

23. Halliwell B, Zentella A, Gomez EO, Kershenobich D (1997) Antioxidants and human disease: a general introduction. Nutr Rev 55(1): S44

24. Hiroko Hassegawa R, Megumi Kasuya MC, Dantas Vanetti MC (2005) Growth and antibacterial activity of Lentinula edodes in liquid media supplemented with agricultural wastes. Electron $\mathrm{J}$ Biotechnol 8(2): 94-99

25. Hohlfeld J, Fabel H, Hamm H (1997) The role of pulmonary surfactant in obstructive airways disease. Eur Respir J 10(2):482-91

26. Jaiganesh R, Kumar NS (2012) Marine bacterial sources of bioactive compounds. Adv Food Nutr Res 65:389-408

27. Jain P and Pundir RK (2011) Effect of fermentation medium, pH and temperature variations on antibacterial soil fungal metabolite production. J Agric Technol 7(2):247-269.

28. Joshi M, Patel H, Gupte S, Gupte, A (2013) Nutrient improvement for simultaneous production of exopolysaccharide and mycelial biomass by submerged cultivation of Schizophyllum commune AGMJ-1 using statistical optimization. 3 Biotech 3(4):307-318

29. Karimi E, Oskoueian E, Hendra R, Jaafar HZ (2010) Evaluation of Crocus sativus L. stigma phenolic and flavonoid compounds and its antioxidant activity. Molecules 15(9): 6244-6256

30. Kawanishi T, Shiraishi T, Okano Y, Sugawara K, Hashimoto M, Maejima K, Komatsu K, Kakizawa S, Yamaji Y, Hamamoto H, Oshima K (2011) New detection systems of bacteria using highly selective media designed by SMART: selective medium-design algorithm restricted by two constraints. PloS one 6(1):e16512 
31. Khalil N, Ashour M, Singab AN, Salama O (2018) Bioassay guided fractionation and cytotoxic activity of Daucus carota var. boissieri. Future J Pharm Sci 4:14-17

https://doi.org/https://doi.org/10.1016/j.jps.2017.07.002

32. Kumari M, Taritla S, Sharma A, Jayabaskaran C (2018) Antiproliferative and antioxidative bioactive compounds in extracts of marine-derived endophytic fungus Talaromyces purpureogenus. Front Microbiol 9: 1777 https://doi.org/10.3389/fmicb.2018.01777

33. Lee YM, Kim MJ, Li H, Zhang P, Bao B, Lee KJ, Jung JH (2013) Marine-derived Aspergillus species as a source of bioactive secondary metabolites. Mar Biotechnol 15(5): 499-519

34. Liyana-Pathirana CM, Shahidi F (2005) Antioxidant activity of commercial soft and hard wheat (Triticum aestivum L.) as affected by gastric pH conditions. J Agric Food Chem 53(7):2433-2440

35. Luong, HX, Thanh TT, Tran TH (2020) Antimicrobial peptides-Advances in development of therapeutic applications. Life Sci 260:118407 doi: 10.1016/j.Ifs.2020.118407

36. Miao L, Qian PY (2005) Antagonistic antimicrobial activity of marine fungi and bacteria isolated from marine biofilm and seawaters of Hong Kong Aquat Microb Ecol 38(3): 231-238

37. Mogensen JE, Sehgal P, Otzen DE (2005) Activation, inhibition, and destabilization of Thermomyces lanuginosus lipase by detergents. Biochemistry 44(5): 1719-1730

38. Ng TB (2005) Mushroom Proteins Related to Host Defense. Int J Med Mushrooms 7:221-236 DOI: 10.1615/IntJMedMushr.v7.i12.210

39. Ottoni CA, Simões MF, Fernandes S, Dos Santos JG, Da Silva ES, de Souza RF, Maiorano AE (2017) Screening of filamentous fungi for antimicrobial silver nanoparticles synthesis. AMB Express 7(1):10

40. Pannippara MA, Kesav S, Raghavan R M K N, Mathew A, Bhat SG, Kozhiyil EK (2020) Characterization and Potent Application of Pleurotus floridanus Trypsin Inhibitor (PfTI). Nat Prod Sci 26(3): 207-213

41. Petit KE, Mondeguer F, Roquebert MF, Biard JF, Pouchus YF (2004) Detection of griseofulvin in a marine strain of Penicillium waksmanii by ion trap mass spectrometry. J Microbiol Methods 58(1): 59-65

42. Raghavan RM, Pannippara MA, Kesav S, Mathew A, Bhat SG, Aa MH, Elyas KK (2021) MFAP9: Characterization of an extracellular thermostable antibacterial peptide from marine fungus with biofilm eradication potential. J Pharm Biomed Anal 194:113808 https://doi.org/10.1016/j.jpba.2020.113808

43. Raheema AS, Aswini C, Sathya M, Merish S, Walter TM (2014) In-vitro anti-inflammatory screening of a poly herbal siddha medicine,"ashwathi chooranam". Int J Pharm Sci Res 5(10): 4395-4399

44. Raja K, Martin L C, Bose L, Sahayanathan GJ, Padmanaban D, Chinnasamy A (2020) Antiproliferative and apoptotic effects of by-product (skin extract) from marine catfish Tachysurus dussumieri. Biocatal Agric Biotechnol 29: 101816

45. Rajasekar T, Balaji S, Kumaran S, Deivasigamani B, Pugzhavendhan SR (2012) Isolation and characterization of Marine fungal metabolites against clinical pathogens. Asian Pac J Trop Dis 2: 
S387-S392

46. Robles-Fort A, García-Robles I, Fernando W, Hoskin DW, Rausell C, Real, MD (2021) Dual antimicrobial and antiproliferative activity of TcPaSK peptide derived from a Tribolium castaneum insect defensin. Microorganisms 9(2):222 https://doi.org/10.3390/microorganisms9020222

47. Silva C, Correia-Branco A, Andrade N, Ferreira AC, Soares ML, Sonveaux P, Stephenne J, Martel F (2019) Selective pro-apoptotic and antimigratory effects of polyphenol complex catechin: lysine 1:2 in breast, pancreatic and colorectal cancer cell lines. Eur J Pharmacol 859:172533 https://doi.org/ https://doi.org/10.1016/j.ejphar.2019.172533

48. Silva FD, Rezende CA, Rossi DC, Esteves E, Dyszy FH, Schreier S, Daffre S (2009) Structure and mode of action of microplusin, a copper II-chelating antimicrobial peptide from the cattle tick Rhipicephalus (Boophilus) microplus. J Biol Chem 284(50): 34735-34746

49. Skouri-Gargouri H, Jellouli-Chaker N, Gargouri A (2010) Factors affecting production and stability of the AcAFP antifungal peptide secreted by Aspergillus clavatus. Appl Microbiol Biotechnol 86(2): 535543

50. Suarez-Jimenez GM, Burgos-Hernandez A, Ezquerra-Brauer JM (2012) Bioactive peptides and depsipeptides with anticancer potential: sources from marine animals. Mar Drugs 10: 963- 986

51. Theis T, Wedde M, Meyer V, Stahl U (2003) The antifungal protein from Aspergillus giganteus causes membrane permeabilization. Antimicrob Agents Chemother 47(2):588-593.

52. Wen $C$, Chen X (2014) Purification and identification of a novel antifungal protein secreted by Penicillium citrinum from the Southwest Indian Ocean. J Microbiol Biotechnol 24(10): 1337-1345

53. Xie J, Zhang R, Shang C, Guo Y (2009) Isolation and characterization of a bacteriocin produced by an isolated Bacillus subtilis LFB112 that exhibits antimicrobial activity against domestic animal pathogens. Afr J Biotechnol 8(20):5611-5619

54. Xu K, Gao H, Shu HKG (2011) Celecoxib can induce vascular endothelial growth factor expression and tumor angiogenesis. Mol Cancer Ther 10(1):138-147

55. Xueqin W, Huahua Y, Ronge X, Pengcheng L (2017) Characterization, Preparation, and Purification of Marine Bioactive Peptides: Review Article. BioMed Res Int 9746720.

56. Zan X, Cui F, Li Y, Yang Y, Wu D, Sun W, Ping L (2015) Hericium erinaceus polysaccharide-protein HEG-5 inhibits SGC-7901 cell growth via cell cycle arrest and apoptosis. Int J Biol Macromol 76: 242253

57. Zhang T, Liu H, Li Y, Li C, Wan G, Chen B, Wang Y (2019) A pH-sensitive nanotherapeutic system based on a marine sulfated polysaccharide for the treatment of metastatic breast cancer through combining chemotherapy and COX-2 inhibition. Acta Biomater 99: 412-425

58. Zheng J, Zhu H, Hong K, Wang Y, Liu P, Wang X, Zhu W et al (2009) Novel cyclic hexapeptides from marine-derived fungus, Aspergillus sclerotiorum PT06-1. Org Lett 11(22):5262-5265.

\section{Figures}




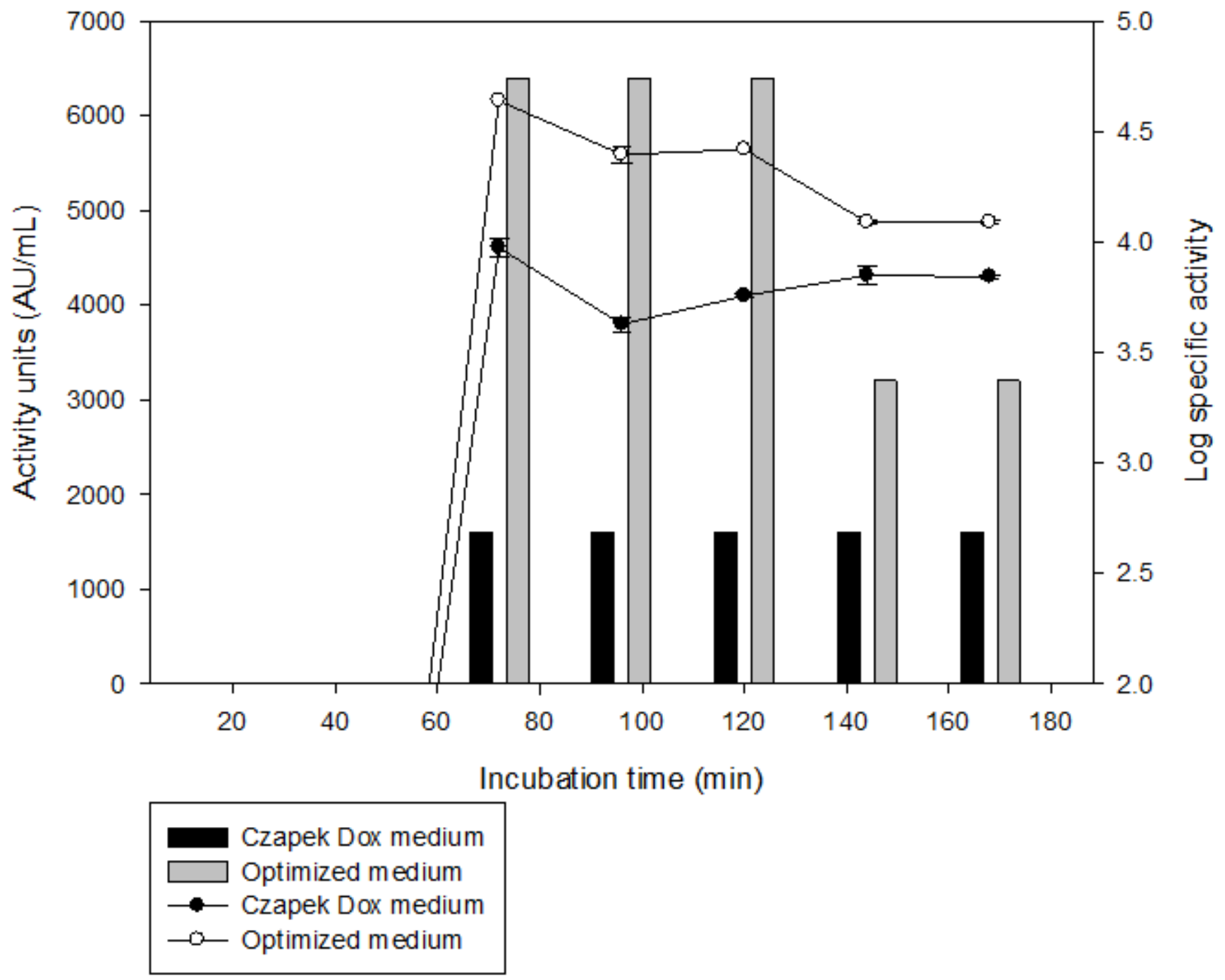

Figure 1

Time course experiment for peptide production by BTMF9 


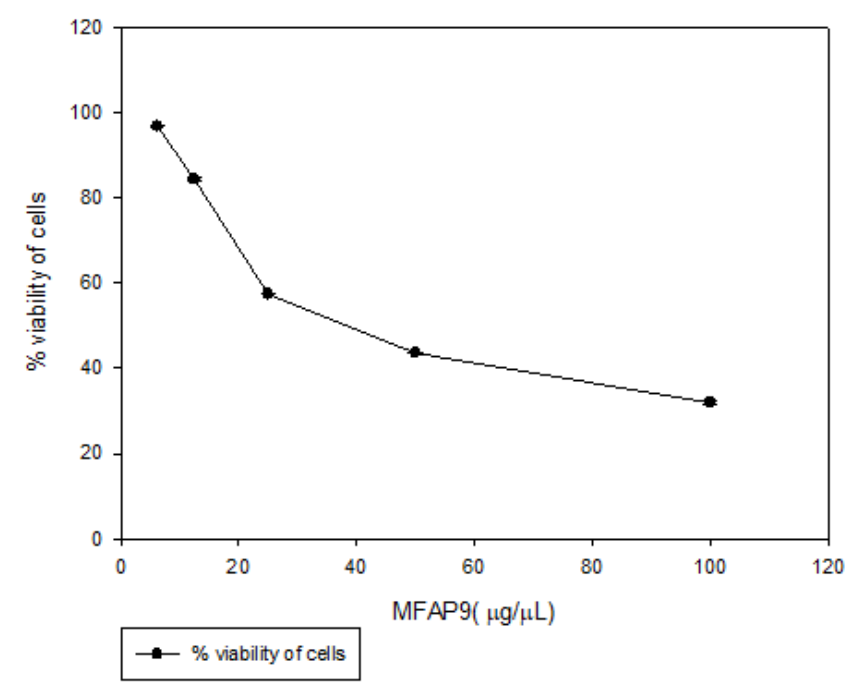

A

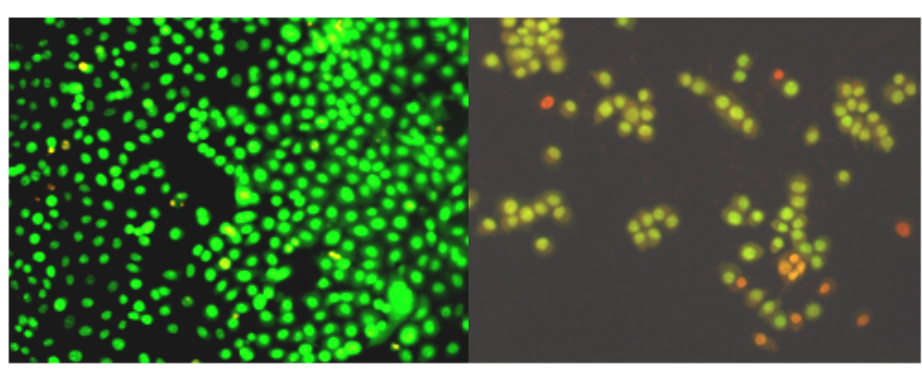

$\mathrm{D}$

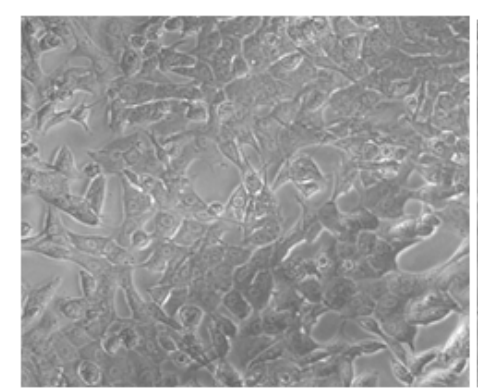

B

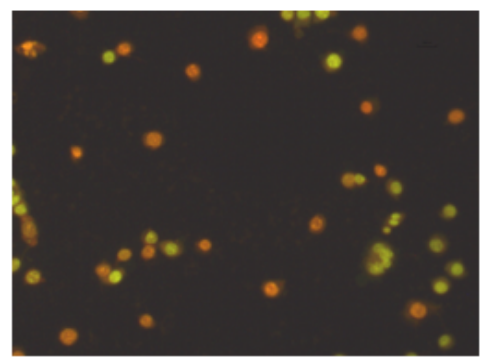

$\mathrm{F}$

\section{Figure 2}

A. In vitro antiproliferative effect of peptide MFAP9 on A549 cancer cell lines. Cytoyoxicity of peptide MFAP9 on A549 cancer cell lines. B. Control cells C. MFAP9 treated cell lines. Morphological changes in A549 cells after treatment with MFAP9 and then staining with acridine orange (AO)/ethidium bromide (EtBr). D. Control cells E. $50 \mu \mathrm{g} / \mathrm{mL}$ MFAP9 treated cell line F. $100 \mu \mathrm{g} / \mathrm{mL}$ MFAP9 treated cell line 


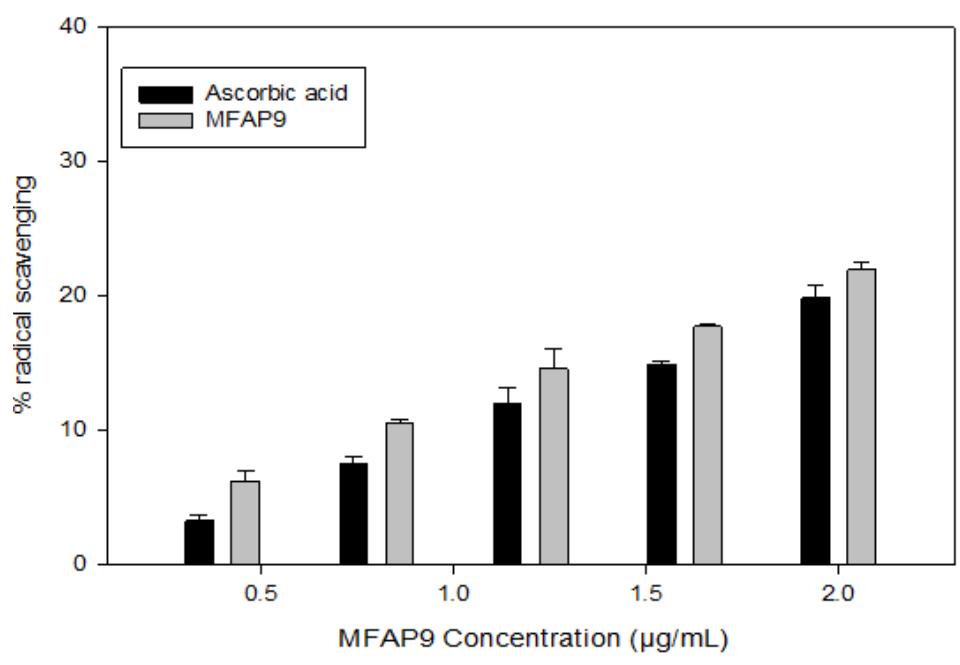

A

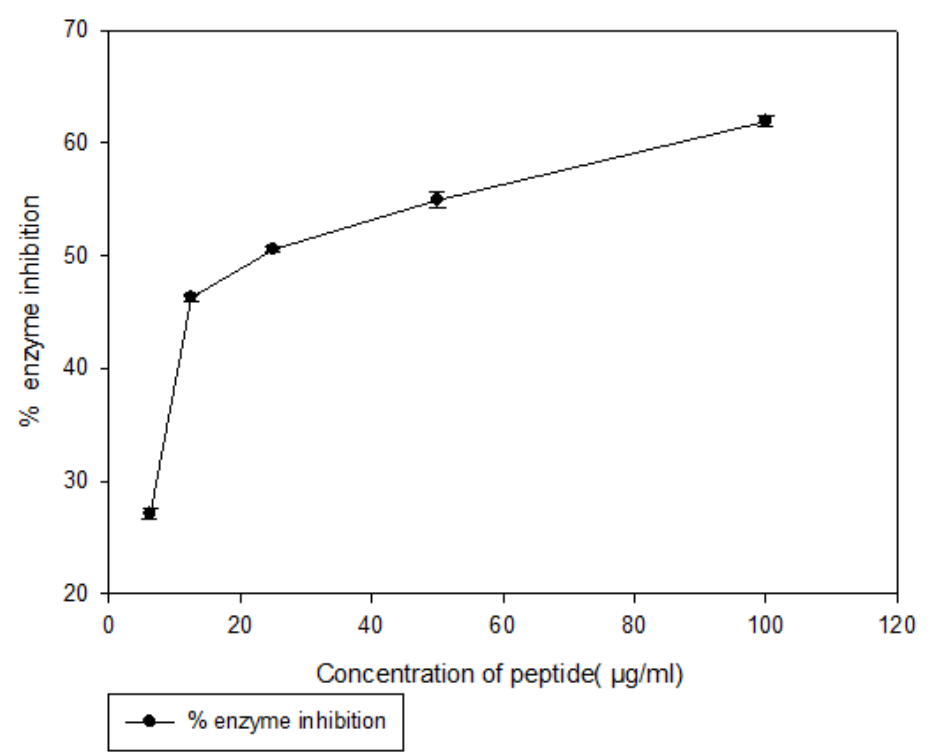

B

\section{Figure 3}

A. DPPH assay using standard ascorbic acid and peptide MFAP9. B. Anti-inflammatory assay derived by spectroscopic analysis: Inhibition of COX-2 by MFAP9. 